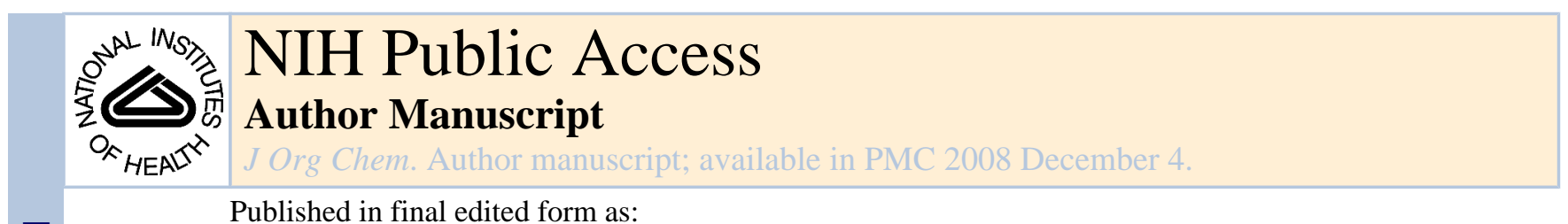

J Org Chem. 2007 November 9; 72(23): 8958-8961. doi:10.1021/jo701694k.

\title{
Syntheses of Lewis ${ }^{x}$ and Dimeric Lewis $\mathrm{x}$ : Construction of Branched Oligosaccharides by a Combination of Pre-activation and Reactivity Based Chemoselective One-Pot Glycosylations
}

\author{
Adeline Miermont ${ }^{\dagger}, \|$, Youlin Zeng ${ }^{\dagger}, \|$, Yuqing Jing ${ }^{\dagger}$, Xin-shan Ye§, and Xuefei Huang ${ }^{\dagger},{ }^{*}$ \\ $\dagger$ Department of Chemistry, The University of Toledo, 2801 W. Bancroft Street, MS 602, Toledo, Ohio 43606 \\ $\S$ The State Key Laboratory of Natural and Biomimetic Drugs, School of Pharmaceutical Sciences, Peking \\ University, Xue Yuan Rd. 38, Beijing 100083, China
}

\section{Abstract}

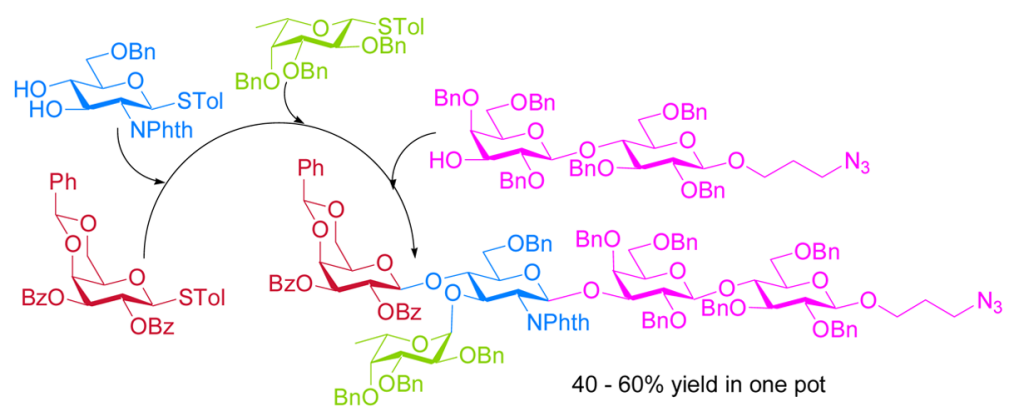

Two asymmetrically branched oligosaccharides, Lewis ${ }^{\mathrm{X}}$ and dimeric Lewis ${ }^{\mathrm{X}}$ were assembled in onepot with high yields and exclusive regio- and stereo-selectivities. $p$-Tolyl thioglycosides were utilized as the sole type of building blocks, thus simplifying the overall synthetic design. The reactivity independent nature of the pre-activation based method allows modular assembly of the dimeric Lewis ${ }^{X}$ octasaccharide without the need for tedious protective group manipulation to achieve exact anomeric reactivities.

The Lewis family of oligosaccharides, as represented by Lewis ${ }^{\mathrm{X}}$ pentasaccharide $\mathbf{1}$ and dimeric Lewis $\mathrm{X}$ octasaccharide $\mathbf{2}$, is involved in a wide array of biological events, such as modulation of immune system towards a Th2 response, ${ }^{1}$ bacterial and viral infection. ${ }^{2,3}$ In addition, they are known to be over-expressed on tumor cell surface, 4,5 thus providing a promising target for carbohydrate based anti-cancer vaccine studies. ${ }^{6}$ With their biological significance, structural and stereochemical complexities, Lewis antigens have served as targets for the development of new synthetic methodologies, 7,8 including automated solid phase synthesis, 9 automated parallel synthesis in solution, ${ }^{7}$ soluble polymer supported synthesis, ${ }^{10}$ and reactivity based chemoselective glycosylation. ${ }^{11,12}$

Recently, we have developed a pre-activation based chemoselective one-pot glycosylation method, where a thioglycosyl donor is activated in the absence of an acceptor. ${ }^{13}$ Upon completion of the activation, addition of a thioglycosyl acceptor will lead to the formation of a disaccharide containing a thioaryl aglycon, ready for the next round of pre-activation and

Xuefei.huang@utoledo.edu.

These authors have contributed equally to this work. 
glycosylation. Multiple glycosylations can be performed in a single reaction flask without intermediate oligosaccharide purifications, thus significantly expediting the glycoassembly process. We have demonstrated that this is a powerful methodology, which has been successfully applied in syntheses of linear oligosaccharides, including hyaluronic acid oligosaccharides, ${ }^{14}$ heparin trisaccharides, ${ }^{15}$ chitotetraose, ${ }^{16}$ and GloboH. ${ }^{17}$ Herein, we report the application of the pre-activation based methodology to one-pot construction of branched oligosaccharides.
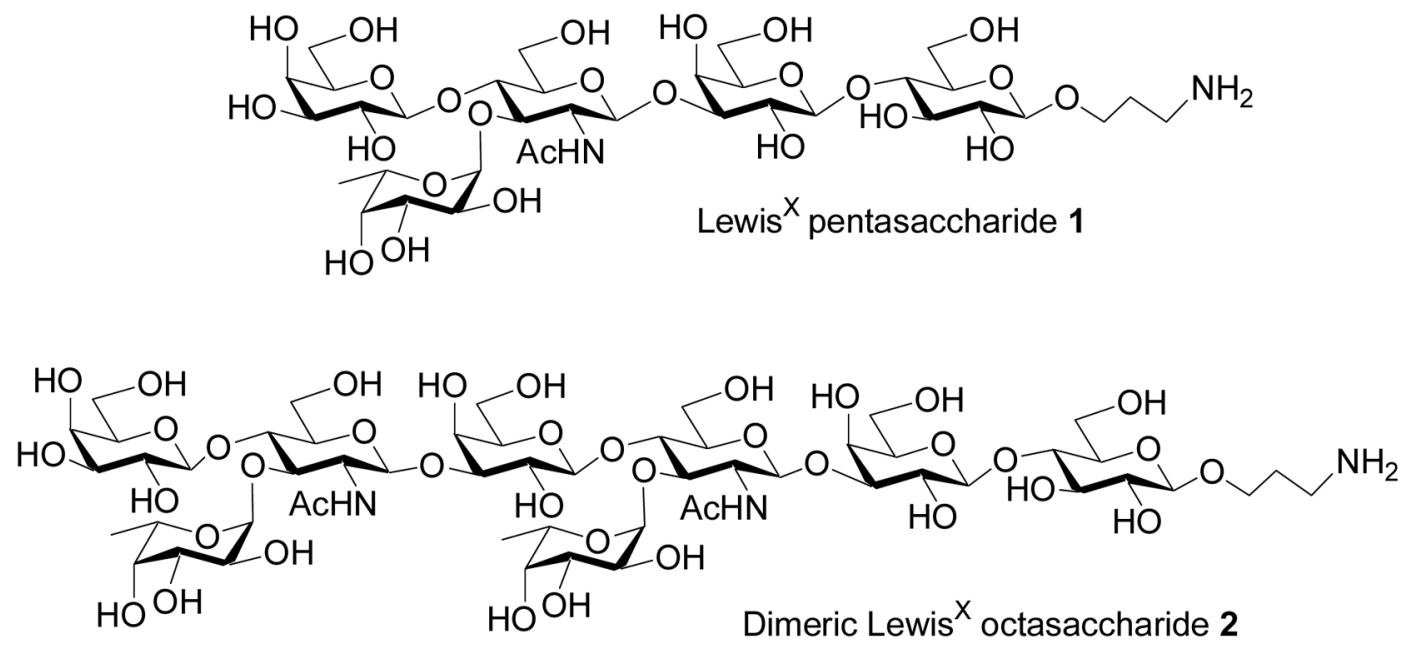

It is a challenging task to assemble Lewis antigens $\mathbf{1}$ and $\mathbf{2}$ in one pot. It is well known that 4hydroxyl group of glucosamine derivatives has very low nucleophilicity. ${ }^{18}$ In addition, fucosylation on 3-OH needs to be carried out with high $\alpha$ selectivity for efficient one pot synthesis. The in situ anomerization procedure for introducing $\alpha$ fucosyl linkage 19,20 is not applicable since the reaction condition cannot be extended to $\beta$ glycosylations. Furthermore, the rate of glycosylation using in situ anomerization procedure is low requiring room temperature overnight, which is undesirable for multiple sequential glycosylations in one pot. To overcome these difficulties, we designed building blocks $\mathbf{3}$ to $\mathbf{8}$ with glucosamine diol $\mathbf{6}$ serving as a key compound. Keeping C 3 hydroxyl group of $\mathbf{6}$ unprotected reduces steric hinderance to $\mathrm{C} 4$ hydroxyl group thus increasing its nucleophilicity. In addition, this allows fucosylation on $\mathrm{C} 3-\mathrm{OH}$ immediately following $\beta$-glycosylation of $\mathrm{C} 4-\mathrm{OH}$ without the need to remove C-3 protective group. The $N$-Phth moiety in $\mathbf{6}$ is crucial to ensure exclusive regioselectivity for $\beta$-galactosylation of $4-\mathrm{OH}$, as smaller Troc, ${ }^{21}$ azido or acetamido groups $^{22}$ on C-2 led to regio-isomers. Diol 8 was examined initially as the lactoside acceptor with its axial 4-OH assumed to be much less reactive than the equatorial $3-\mathrm{OH} .{ }^{10,12,23,24}$ However, glycosylation of $\mathbf{8}$ produced two regio-isomeric oligosaccharides in similar quantities. ${ }^{25}$ The lack of regioselectivity led to the use of lactoside acceptor 7 for our synthesis. 26

Pre-activation of galactoside 3 in dichloromethane (DCM) at $-78^{\circ} \mathrm{C}$ by $p$-TolSOTf, ${ }^{13}$ formed in situ through reaction of $p$-TolSCl and AgOTf, was followed by addition of acceptor $\mathbf{6}$ and a sterically hindered base, tri-tertbutyl-pyrimidine (TTBP) ${ }^{27}$ (Table 1, entry 1). TLC analysis indicated that acceptor $\mathbf{6}$ disappeared within just a few minutes. Fucosyl donor $\mathbf{5}$ was then added to the reaction mixture as a solution in diethyl ether, a solvent known to favor the formation of thermodynamically more stable axial product. ${ }^{28-30}$ Because the armed fucosyl donor 5 has high anomeric reactivity, ${ }^{31}$ addition of another equivalent of $p$-TolSCl chemoselectively activated 5 leading to trisaccharide 10. Lactoside 7 was then added followed 
by AgOTf and $p$-TolSCl producing the fully protected Lewis ${ }^{\mathrm{X}}$ pentasaccharide $\mathbf{1 1}$ with 40 $60 \%$ yield in just 4 hours for this four-component one pot synthesis.

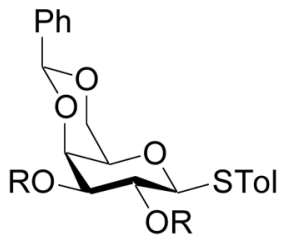

3: $R=B z$

4: $R=$ Lev

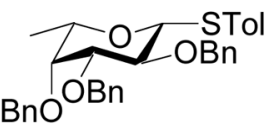

5

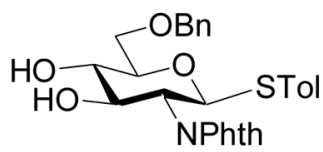

6
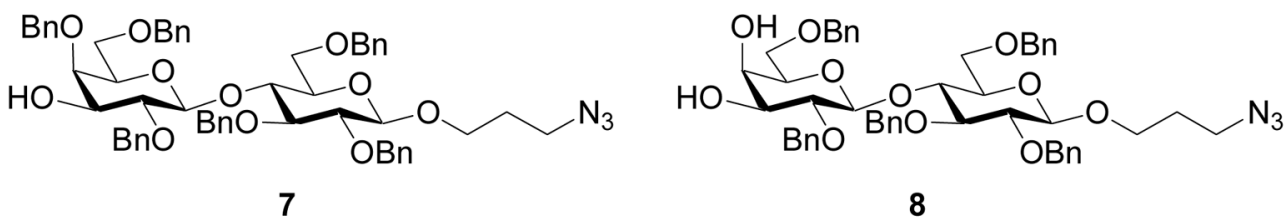

In a separate experiment, the one pot reaction was stopped prior to addition of the lactoside acceptor 7, from which trisaccharide $\mathbf{1 0}$ was isolated as the sole trisaccharide in an excellent $68 \%$ yield (Table 1, entry 2). Trisaccharide 10 was characterized by extensive NMR experiments. Correlations of anomeric carbon of Gal unit ( $99.8 \mathrm{ppm})$ with $\mathrm{H}_{4}$ of $\mathrm{GlcN}$ (4.25 ppm) and anomeric carbon of Fuc ( $98.0 \mathrm{ppm})$ with $\mathrm{H}_{3}$ of $\mathrm{GlcN}(4.68 \mathrm{ppm})$ were observed in its gHMBC spectrum confirming that galactosylation occurred exclusively on the $\mathrm{C} 4-\mathrm{OH}$ of diol 6. The anomeric configurations of newly formed glycosyl linkages were established by coupling constants of anomeric protons ( $\mathrm{Gal} 4.99 \mathrm{ppm},{ }^{3} \mathrm{~J}_{\mathrm{H} 1, \mathrm{H} 2}=7.8 \mathrm{~Hz}$ indicating $\beta$ linkage; Fuc $4.64 \mathrm{ppm},{ }^{3} \mathrm{~J}_{\mathrm{H} 1, \mathrm{H} 2}=4.2 \mathrm{~Hz}$ suggesting $\alpha$ linkage).

Recently, an elegant synthesis of Lewis ${ }^{\mathrm{X}}$ pentasaccharide ${ }^{9}$ was reported using the automated solid phase synthesis method pioneered by Seeberger and coworkers. ${ }^{32}$ The glycoassembly process on the carbohydrate synthesizer took 18 hours using $10-15$ eq. of each glycosyl building block with a $12.7 \%$ overall yield. As a comparison, through one pot synthesis,

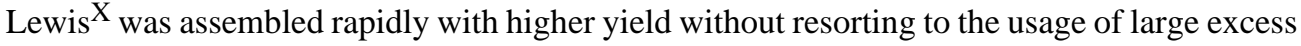
of building blocks, which can be very tedious to prepare. Furthermore, the progress of the one pot synthesis can be easily followed by TLC allowing convenient reaction monitoring and the intermediate oligosaccharide can be readily characterized as demonstrated by trisaccharide 10. This highlights that our one-pot method complements well with the existing automated solid phase synthesis method. 


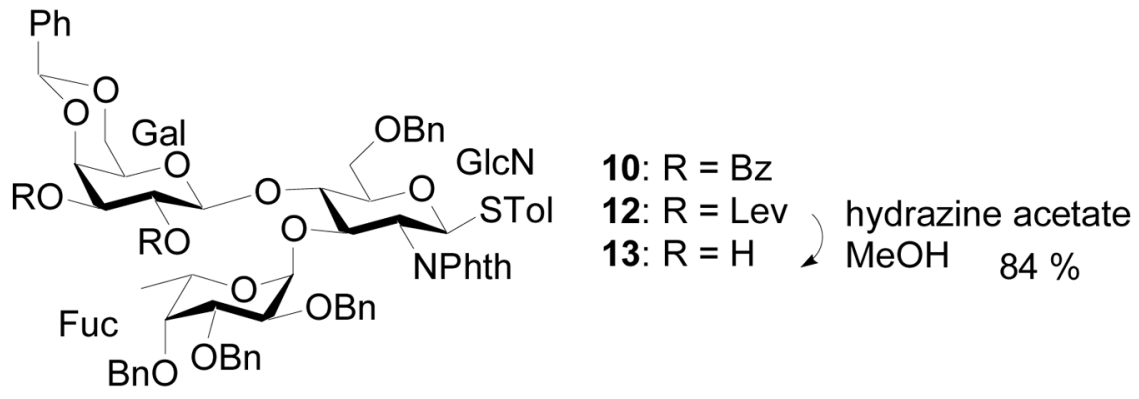

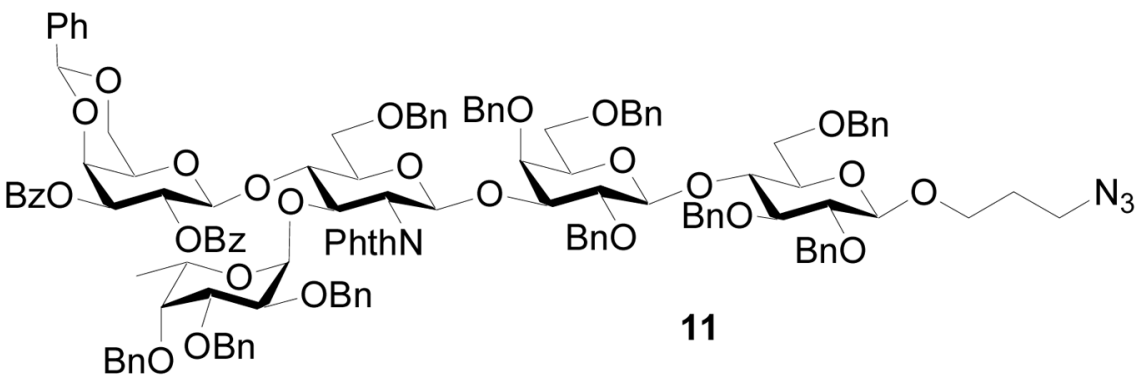

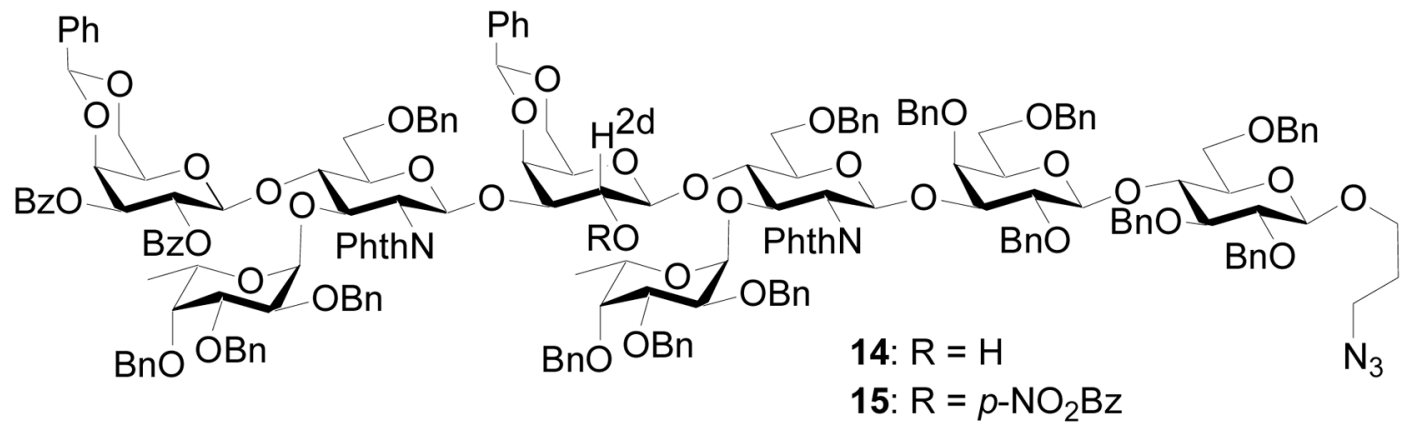

For a highly convergent synthesis of dimeric Lewis ${ }^{\mathrm{X}}$, we designed three modules, trisaccharide donor 10, bifunctional trisaccharide acceptor $\mathbf{1 3}$ and lactoside 7. To simplify the overall synthetic design without relying on selective activation of different types of glycosyl donors, 7 the same aglycon leaving group $p$-STol was used for $\mathbf{1 0}$ and 13. If the traditional armeddisarmed chemoselective glycosylation approach ${ }^{31,33}$ were to be applied, the acceptor must be less reactive than the glycosyl donor. This would require manipulations of the protective groups to significantly decrease the relative anomeric reactivity of the trisaccharide acceptor 13, which can be difficult due to the large number of protective groups present. Because donor activation and addition of acceptor occur at two distinct steps using the pre-activation based method, anomeric reactivities of glycosyl donor and acceptor are independent of each other. 13 This would allow the direct glycosylation of trisaccharide $\mathbf{1 3}$ by trisaccharide $\mathbf{1 0}$, even though $\mathbf{1 0}$ is less reactive.

Diol 13 was prepared by hydrazine acetate treatment of trisaccharide 12, which was obtained by one pot sequential reactions of galactoside $\mathbf{4}$ with glucosamine $\mathbf{5}$ and fucose $\mathbf{6}$ in a similar fashion as the formation of $\mathbf{1 0}$ (Table 1, entry 3 ). With all the necessary building blocks in hand, synthesis of dimeric Lewis ${ }^{X}$ octasaccharide was carried out in one pot (Table 1, entry 4). The trisaccharide donor $\mathbf{1 0}$ was preactivated by $p$-TolSCl/AgOTf, followed by addition of acceptor 13. After complete consumption of $\mathbf{1 3}$ was confirmed by TLC analysis, the lactose acceptor 7 was added followed by another equivalent of $p$-TolSCl/AgOTf. The desired fully protected dimeric Lewis ${ }^{\mathrm{X}}$ octasaccharide 14 was successfully acquired in $44-61 \%$ yield. 
Glycosylation on 3-OH of trisaccharide 13 was confirmed by ${ }^{1} \mathrm{H}-\mathrm{NMR}$ analysis of the $p$ nitrobenzoate derivative of $\mathbf{1 4}$ (octasaccharide 15) with its $\mathrm{H}_{2 \mathrm{~d}}$ proton appearing at $5.25 \mathrm{ppm}$ as a triplet $\left({ }^{3} \mathrm{~J}=9.0 \mathrm{~Hz}\right)$.

Deprotection of Lewis ${ }^{X}$ pentasaccharide $\mathbf{1 1}$ was performed by removal of benzoyl and Phth with ethylenediamine, followed by selective acetylation of the free amine leading to pentasaccharide 16 (Scheme 1a). Attempts to simultaneously reduce the azido moiety and benzyl groups in 16 through catalytic hydrogenation with $\mathrm{Pd} / \mathrm{C}$ or $\mathrm{Pd}(\mathrm{OH})_{2}$ under atmospheric pressure or high pressure $(100 \sim 250 \mathrm{psi})$ hydrogen gas failed to yield any desired product. ${ }^{1} \mathrm{H}-\mathrm{NMR}$ of the reaction mixture showed complex mix of compounds. Instead, Staudinger reduction of the azide moiety in $\mathbf{1 6}$ by trimethylphosphine under basic condition gave the amine, ${ }^{17}$ which underwent smooth hydrogenolysis with $\mathrm{Pd}(\mathrm{OH})_{2}$ to produce desired fully deprotected Lewis ${ }^{\mathrm{X}} \mathbf{1}$ as an acetate salt.

For dimeric Lewis ${ }^{\mathrm{X}}$ deprotection, removal of benzoyl and Phth from $\mathbf{1 4}$ and selective acetylation were performed under same conditions as those for Lewis ${ }^{\mathrm{X}} \mathbf{1 1}$. Subsequent Staudinger reduction of $\mathbf{1 7}$ under basic condition, however, led to partial removal of one acetamido moiety. As an alternative, compound $\mathbf{1 7}$ was treated with trimethylphosphine in aqueous THF without any base to give a free amine, which was hydrogenated to produce dimeric Lewis ${ }^{X}$ octasaccharide $\mathbf{2}$ in $35 \%$ overall yield for the four steps (Scheme 1b).

In conclusion, we have demonstrated that branched oligosaccharides can be constructed using the combination of pre-activation and reactivity based one pot synthesis with exclusive regioand stereo-selectivities. High synthetic efficiency was achieved without requiring large excess of building blocks. Single type of glycosyl donors, i.e., $p$-tolyl thioglycosides was used for all glycosylations, thus significantly simplifying overall synthetic design. With its anomeric reactivity independent nature, the pre-activation based chemoselective glycosylation method presents a powerful strategy for modular synthesis of complex oligosaccharides.

\section{Experimental Section}

\section{3-Azidopropyl (2,3-di-O-benzoyl-4,6-O-benzylidene- $\beta$-D-galactopyranosyl)-(1 $\rightarrow 4)-[(2,3,4-$ tri- $O$-benzyl- $\alpha$-L-fucopyranosyl)-( $1 \rightarrow 3)$ ]-(6-O-benzyl-2-deoxy-2- $N$-phthalimido- $\beta$-D- glucopyranosyl)-(1 $\rightarrow 3)-(2,4,6$-tri-O-benzyl- $\beta$-D-galactopyranosyl)-(1 $\rightarrow 4)-2,3,6$-tri-O-benzyl- $\beta$-D-glucopyranoside (11)}

Galactose 3 (100 mg, $0.172 \mathrm{mmol}$ ) was dissolved in DCM ( $3 \mathrm{~mL})$ and stirred at $-78{ }^{\circ} \mathrm{C}$ with freshly activated molecular sieves MS $4 \AA$ (100 mg) for 30 minutes. Silver triflate $(173 \mathrm{mg}$, $0.67 \mathrm{mmol})$ dissolved in acetonitrile $(0.3 \mathrm{~mL})$ was added to the reaction mixture. Five minutes later, orange-colored $p$-TolSCl $(27 \mu \mathrm{L}, 0.172 \mathrm{mmol})$ was added directly into the reaction mixture. This needs to be performed quite quickly in order to prevent the $p$-TolSCl from freezing inside the syringe tip or on the flask wall. The yellow color of the solution quickly dissipated within one minute, indicating the complete consumption of $p$-TolSCl and the complete activation of galactose donor $\mathbf{3}$ was confirmed by TLC analysis. The glucosamine acceptor 4 (78 $\mathrm{mg}, 0.155 \mathrm{mmol})$ along with TTBP ( $43 \mathrm{mg}, 0.172 \mathrm{mmol})$ dissolved in DCM (2 $\mathrm{mL}$ ) was then added drop wise to the reaction mixture. This was stirred for 20 minutes at which point the glucosamine acceptor 4 was completely consumed. The fucose donor 5 (93 mg, 0.172 $\mathrm{mmol})$ and TTBP $(43 \mathrm{mg}, 0.172 \mathrm{mmol})$ dissolved in $\mathrm{Et}_{2} \mathrm{O}(2 \mathrm{~mL})$ were added to the mixture. After 10 minutes, $p$-TolSCl $(27 \mu \mathrm{L}, 0.172 \mathrm{mmol})$ was added into the reaction mixture which was stirred for an additional 45 minutes. When complete consumption of the fucose donor 5 was confirmed by TLC analysis, the lactose acceptor $6(116 \mathrm{mg}, 0.120 \mathrm{mmol})$ and TTBP (43 $\mathrm{mg}, 0.172 \mathrm{mmol})$ were dissolved in DCM $(2 \mathrm{~mL})$ and added to the reaction mixture. This was stirred for 10 minutes at $-78{ }^{\circ} \mathrm{C}$ and then silver triflate $(44 \mathrm{mg}, 0.172 \mathrm{mmol})$ was added. After five minutes, $p$-TolSCl $(27 \mu \mathrm{L}, 0.172 \mathrm{mmol})$ was added into the reaction mixture which was 
stirred for 45 minutes. The mixture was then filtered through Celite and the Celite was washed with DCM until no organic compounds were present in the filtrate. The filtrate was extracted with saturated solution of $\mathrm{NaHCO}_{3}$. The organic layer was then dried over $\mathrm{Na}_{2} \mathrm{SO}_{4}$ and concentrated to dryness. The residue was purified by silica gel column chromatography (Hexanes/DCM/EtOAc, 5:3:2). The desired product was obtained in 40-60\% yield as a white solid. $[\alpha]_{\mathrm{D}}^{25}-44\left(\mathrm{c} 1.5, \mathrm{CH}_{2} \mathrm{Cl}_{2}\right){ }^{1} \mathrm{H}-\mathrm{NMR}\left(600 \mathrm{MHz}, \mathrm{CDCl}_{3}\right): \delta 8.04-6.76(\mathrm{~m}, 69 \mathrm{H}), 5.85(\mathrm{t}$, $\left.1 \mathrm{H},{ }^{3} \mathrm{~J}=9.0 \mathrm{~Hz}\right), 5.56(\mathrm{~s}, 1 \mathrm{H}), 5.19\left(\mathrm{~d}, 1 \mathrm{H},{ }^{3} \mathrm{~J}=7.8 \mathrm{~Hz}\right), 5.17\left(\mathrm{dd}, 1 \mathrm{H},{ }^{3} \mathrm{~J}=4.8,13.8 \mathrm{~Hz}\right), 5.12$ $\left(\mathrm{d}, 1 \mathrm{H},{ }^{3} \mathrm{~J}=12 \mathrm{~Hz}\right), 5.02\left(\mathrm{~d}, 1 \mathrm{H},{ }^{3} \mathrm{~J}=8.4 \mathrm{~Hz}\right), 4.88(\mathrm{~m}, 2 \mathrm{H}), 4.81\left(\mathrm{t}, 2 \mathrm{H},{ }^{3} \mathrm{~J}=10.2 \mathrm{~Hz}\right), 4.75$ $\left(\mathrm{d}, 1 \mathrm{H},{ }^{3} \mathrm{~J}=10.8 \mathrm{~Hz}\right), 4.61\left(\mathrm{~d}, 1 \mathrm{H},{ }^{3} \mathrm{~J}=4.8 \mathrm{~Hz}\right), 4.54-4.49(\mathrm{~m}, 4 \mathrm{H}), 4.44-4.29(\mathrm{~m}, 6 \mathrm{H}), 4.27(\mathrm{~d}$, $\left.1 \mathrm{H},{ }^{3} \mathrm{~J}=11.4 \mathrm{~Hz}\right), 4.19-4.06(\mathrm{~m}, 7 \mathrm{H}), 4.03-3.99(\mathrm{~m}, 2 \mathrm{H}), 3.96(\mathrm{~s}, 1 \mathrm{H}), 3.89\left(\mathrm{dd}, 1 \mathrm{H} .{ }^{3} \mathrm{~J}=2.4\right.$, $10.2 \mathrm{~Hz}), 3.84-3.80(\mathrm{~m}, 2 \mathrm{H}), 3.79(\mathrm{~s}, 1 \mathrm{H}), 3.76\left(\mathrm{~d}, 1 \mathrm{H},{ }^{3} \mathrm{~J}=4.8 \mathrm{~Hz}\right), 3.62\left(\mathrm{~d}, 1 \mathrm{H},{ }^{3} \mathrm{~J}=10.2 \mathrm{~Hz}\right)$, $3.55\left(\mathrm{dd}, 1 \mathrm{H},{ }^{3} \mathrm{~J}=4.8,10.2 \mathrm{~Hz}\right), 3.49-3.43(\mathrm{~m}, 2 \mathrm{H}), 3.41-3.37(\mathrm{~m}, 5 \mathrm{H}), 3.32-3.29(\mathrm{~m}, 4 \mathrm{H}), 3.28$ $\left(\mathrm{q}, 1 \mathrm{H},{ }^{3} \mathrm{~J}=7.8,9.0 \mathrm{~Hz}\right), 3.20\left(\mathrm{~d}, 1 \mathrm{H},{ }^{3} \mathrm{~J}=10.8 \mathrm{~Hz}\right), 3.16(\mathrm{~s}, 1 \mathrm{H}), 2.86\left(\mathrm{~d}, 1 \mathrm{H},{ }^{3} \mathrm{~J}=8.4 \mathrm{~Hz}\right)$, $1.80-1.77(\mathrm{~m}, 2 \mathrm{H}), 1.26\left(\mathrm{~d}, 3 \mathrm{H},{ }^{3} \mathrm{~J}=6.6 \mathrm{~Hz}\right) ;{ }^{13} \mathrm{C}-\mathrm{NMR}\left(150 \mathrm{MHz}, \mathrm{CDCl}_{3}\right) \delta 166.3,164.9$, $139.7,139.7$, 139.6, 139.2, 138.8, 138.6, 138.6, 138.5, 138.4, 138.2 , 137.8, 130.1, 129.9, 129.5, $129.3,128.9$, 128.8, 128.7, 128.6, 128.5, 128.5, 128.4, 128.4, 128.3, 128.3, 128.3, 128.2, 128.1, $128.1,128.1,128.0,127.9,127.9,127.9,127.9,127.8,127.8,127.7,127.6,127.4,127.3,127.2$, $127.1,127.0,126.9,126.4,125.9,103.6,102.8\left({ }^{1} \mathrm{~J}_{\mathrm{C}-\mathrm{H}}=163.4 \mathrm{~Hz}\right), 100.0\left({ }^{1} \mathrm{~J}_{\mathrm{C}-\mathrm{H}}=161.3 \mathrm{~Hz}\right)$, $99.9\left({ }^{1} \mathrm{~J}_{\mathrm{C}-\mathrm{H}}=158.2 \mathrm{~Hz}\right), 99.8\left({ }^{1} \mathrm{~J}_{\mathrm{C}-\mathrm{H}}=164.6 \mathrm{~Hz}\right), 97.6\left({ }^{1} \mathrm{~J}_{\mathrm{C}-\mathrm{H}}=174.1 \mathrm{~Hz}\right), 83.1,82.2,81.8$, 79.2, 78.7, 77.5, 77.2, 77.0, 76.8, 76.2, 75.3, 75.2, 75.0, 74.9, 74.8, 74.1, 73.6, 73.5, 73.2, 73.0, 72.9, 71.6, 66.7, 66.6, 66.5, 48.5, 29.4, 16.5; HRMS [M+Na] ${ }^{+} \mathrm{m} / \mathrm{z}$ : calcd for $\mathrm{C}_{132} \mathrm{H}_{132} \mathrm{~N}_{4} \mathrm{NaO}_{28} 2244.8926$, found 2244.8960 .

\section{3-Aminopropyl $\beta$-D-galactopyranosyl-( $1 \rightarrow 4)$-[( $\alpha$-L-fucopyranosyl)-(1 $\rightarrow 3)]-(2-N$-acetamido-2- deoxy- $\beta$-D-glucopyranosyl)-(1 $\rightarrow 3)-(\beta-D$-galactopyranosyl)-(1 $\rightarrow 4)-\beta$-D-glucopyranoside (1)}

The fully protected pentasaccharide $11(200 \mathrm{mg}, 0.09 \mathrm{mmol})$ was mixed with ethylenediamine $(0.5 \mathrm{~mL})$ in $n$ butanol $(5 \mathrm{~mL})$. The reaction was stirred at $130^{\circ} \mathrm{C}$ for 20 hours. The mixture was then concentrated and the residue was dissolved in DCM and extracted with a saturated solution of $\mathrm{NH}_{4} \mathrm{Cl}$. The organic layer was dried over $\mathrm{Na}_{2} \mathrm{SO}_{4}$ and concentrated to dryness. The crude residue was purified by silica gel column chromatography. The desired product was obtained in its pure form as an off-white solid. The newly formed compound was then dissolved in $\mathrm{MeOH}(5 \mathrm{~mL})$ along with triethylamine $(0.1 \mathrm{~mL})$ and acetic anhydride $(0.1 \mathrm{~mL}, 15 \mathrm{eq})$. The reaction mixture was stirred at room temperature for 4 hours. It was then concentrated and the residue was dissolved in DCM and extracted with a saturated solution of $\mathrm{NH}_{4} \mathrm{Cl}$. The organic layer was dried over $\mathrm{Na}_{2} \mathrm{SO}_{4}$ and concentrated to dryness. The crude residue was purified by silica gel column chromatography (Hexanes/EtOAc, $1: 1 \rightarrow 1: 3$ ) to afford the pentasaccharide 16 as a white solid. A mixture of $16(100 \mathrm{mg}, 0.052 \mathrm{mmol}), 1 \mathrm{M}$ solution of $\mathrm{PMe}_{3}$ in THF $(0.360 \mathrm{~mL}, 7 \mathrm{eq})$ and $0.1 \mathrm{M} \mathrm{NaOH}(0.5 \mathrm{~mL})$ in THF was stirred at $60{ }^{\circ} \mathrm{C}$ overnight. The mixture was then concentrated and the resulting residue was dissolved in DCM and extracted twice with $\mathrm{H}_{2} \mathrm{O}$. The organic layer was dried over $\mathrm{Na}_{2} \mathrm{SO}_{4}$ and concentrated to dryness. The crude product was purified by silica gel column chromatography (DCM $\rightarrow$ DCM/MeOH 8:1). The desired product bearing a terminal free amine was obtained as an off-white solid. Finally a mixture of this product $(80 \mathrm{mg}, 0.042 \mathrm{mmol})$ and $\mathrm{Pd}(\mathrm{OH})_{2}(80 \mathrm{mg})$ in $\mathrm{DCM} / \mathrm{MeOH} / \mathrm{H}_{2} \mathrm{O} /$ $\mathrm{AcOH}(1 \mathrm{~mL}: 1 \mathrm{~mL}: 2 \mathrm{~mL}: 2 \mathrm{~mL})$ was stirred at room temperature under atmospheric pressure $\mathrm{H}_{2}$ for 24 hours. The mixture was filtered through Celite, concentrated and extracted with DCM (3 times) and EtOAc (3 times). The water layer was then lyophilized to afford a white solid which was purified by Sephadex G-10 size exclusion column. The pure Lewis $\mathrm{X}$

pentasaccharide 1 was obtained in acetate form as a solid in $53 \%$ yield over four steps. $[\alpha]_{\mathrm{D}}^{25}$ -217 (c 0.5, $\left.\mathrm{H}_{2} \mathrm{O}\right){ }^{1} \mathrm{H}-\mathrm{NMR}\left(600 \mathrm{MHz}, \mathrm{D}_{2} \mathrm{O}\right) \delta 4.94\left(\mathrm{~d}, 1 \mathrm{H},{ }^{3} \mathrm{~J}=3.6 \mathrm{~Hz}\right), 4.52\left(\mathrm{~d}, 1 \mathrm{H},{ }^{3} \mathrm{~J}=8.4\right.$ $\mathrm{Hz}), 4.33\left(\mathrm{~d}, 1 \mathrm{H},{ }^{3} \mathrm{~J}=8.4 \mathrm{~Hz}\right), 4.28\left(\mathrm{~d}, 1 \mathrm{H},{ }^{3} \mathrm{~J}=8.4 \mathrm{~Hz}\right), 4.25\left(\mathrm{~d}, 1 \mathrm{H},{ }^{3} \mathrm{~J}=8.4 \mathrm{~Hz}\right), 3.97(\mathrm{~d}$, $\left.1 \mathrm{H},{ }^{3} \mathrm{~J}=2.4 \mathrm{~Hz}\right), 3.80-3.75(\mathrm{~m}, 4 \mathrm{H}), 3.73-3.69(\mathrm{~m}, 4 \mathrm{H}), 3.63-3.37(\mathrm{~m}, 20 \mathrm{H}), 3.31\left(\mathrm{t}, 1 \mathrm{H},{ }^{3} \mathrm{~J}=\right.$ 
$7.2 \mathrm{~Hz}), 3.16-3.13(\mathrm{~m}, 2 \mathrm{H}), 2.97\left(\mathrm{t}, 2 \mathrm{H},{ }^{3} \mathrm{~J}=7.2 \mathrm{~Hz}\right), 1.83(\mathrm{~s}, 3 \mathrm{H}), 0.99\left(\mathrm{~d}, 3 \mathrm{H},{ }^{3} \mathrm{~J}=6.0\right.$ $\mathrm{Hz}) ;{ }^{13} \mathrm{C}-\mathrm{NMR}\left(150 \mathrm{MHz}, \mathrm{D}_{2} \mathrm{O}\right) \delta 181.7,174.8,103.0,102.7,102.2,101.9,98.7,82.2,78.4$, 75.2, 75.1, 75.0, 74.9, 74.4, 73.1, 72.8, 72.6, 72.0, 71.1, 70.0, 69.3, 68.5, 68.4, 68.0, 67.8, 66.8, 61.6, 61.1, 60.1, 59.7, 56.1, 37.7, 26.8, 23.4, 22.4, 15.4; HRMS [M+Na] ${ }^{+} \mathrm{m} / \mathrm{z}$ : calcd for $\mathrm{C}_{35} \mathrm{H}_{62} \mathrm{~N}_{2} \mathrm{NaO}_{25}$ 933.3539, found 933.3531.

\section{Supplementary Material}

Refer to Web version on PubMed Central for supplementary material.

\section{Acknowledgements}

We are grateful for financial supports from the University of Toledo, the National Institutes of Health (R01-GM-72667) and the Pardee foundation.

\section{References}

1. Okano, M.; Nishizaki, K.; Da'dara, A.; Thomas, P.; Carter, M.; Harn, DAJ. Vaccine Adjuvants. Hackett, CJ.; Harn, DAJ., editors. Humana Press Inc.; Totowa, N. J: 2006. p. 177-191.

2. de Witte L, Nabatov A, Pion M, Fluitsma D, de Jong MAWP, de Gruijl T, Piguet V, van Kooyk Y, Geijtenbeek TBH. Nat Med 2007;13:367-371. [PubMed: 17334373]

3. Chmiela M, Wadstrom T, Folkesson H, Malecka IP, Czkwianianc T, Rechciñski T, Rudnicka W. Immunol Lett 1998;61:119-125. [PubMed: 9657264]

4. Holmes EH, Hakomori S, Ostrander GK. J Biol Chem 1987;262:15649-15658. [PubMed: 2960671]

5. Fukushi Y, Hakomori S, Nudelman E, Cochran N. J Biol Chem 1984;259:4681-4685. [PubMed: 6200484]

6. Danishefsky SJ, Allen JR. Angew Chem Int Ed 2000;39:836-863.

7. Tanaka H, Matoba N, Tsukamoto H, Takimoto H, Yamada H, Takahashi T. Synlett 2005:824-828. and references cited therein

8. An excellent review on Lewis family oligosaccharide and sphingolipid syntheses: Vankara YD, Schmidt RR. Chem Soc Rev 2000;29:201-216.and references cited therein

9. Love KR, Seeberger PH. Angew Chem Int Ed 2004;43:602-605.

10. Zhu T, Boons GJ. Chem Eur J 2001;7:2382-2389.

11. Mong KKT, Wong CH. Angew Chem Int Ed 2002;41:4087-4090.

12. Zhang Z, Niikura K, Huang X, Wong CH. Can J Chem 2002;121:1051-1054.

13. Huang X, Huang L, Wang H, Ye XS. Angew Chem Int Ed 2004;42:5221-5224.

14. Huang L, Huang X. Chem Eur J 2007;13:529-540.

15. Huang L, Teumelsan N, Huang X. Chem Eur J 2006;12:5246-5252.

16. Huang L, Wang Z, Li X, Ye XS, Huang X. Carbohydr Res 2006;341:1669-1679. [PubMed: 16442505]

17. Wang Z, Zhou L, El-Boubbou K, Ye XS, Huang X. J Org Chem 2007;72in press

18. Crich D, Dudkin V. J Am Chem Soc 2001;123:6819-6825. [PubMed: 11448186]

19. Shao N, Guo ZW. Pol J Chem 2005;79:297-307.

20. Vermeer HJ, Van Dijk CM, Kamerling JP, Vliegenthart JFG. Eur J Org Chem 2001:193-203.and references cited therein

21. Koeller KM, Wong CH. Chem Eur J 2000;6:1243-1251.

22. Ellervik U, Magnusson G. J Org Chem 1998;63:9314-9322.

23. Lahmann M, Bülow L, Teodorovic P, Gybäck H, Oscarson S. Glycoconj J 2004;21:251-256. [PubMed: 15486457]

24. Andersen SM, Ling CC, Zhang P, Townson K, Willison HJ, Bundle DR. Org Biomol Chem 2004;2:1199-1212. [PubMed: 15064799] 
25. Jing, Y. Fluorous Thiols in Oligosaccharide Synthesis and Iterative One-pot Synthesis of Tumorassociated Carbohydrate Antigen Lewis ${ }^{X}$ Pentasaccharide. Department of Chemistry; University of Toledo:; M. S. thesis, Toledo, Ohio: 2005.

26. Aly MRE, Castro-Palomino JC, Ibrahim ESI, El-Ashry ESH, Schmidt RR. Eur J Org Chem 1998:2305-2316.

27. Crich D, Smith M, Yao Q, Picione J. Synthesis 2001:323-326.

28. Chiba H, Funasaka S, Mukaiyama T. Bull Chem Soc Jpn 2003;76:1629-1644.

29. Adinolfi M, Barone G, Iadonisi A, Schiattarella M. Tetrahedron Lett 2002;43:5573-5577.

30. Wulff G, Rohle G. Angew Chem Int Ed 1974;13:157-170.

31. Koeller KM, Wong CH. Chem Rev 2000;100:4465-4493. [PubMed: 11749355]

32. Seeberger PH. Chem Commun 2003:1115-1121.

33. Mootoo DR, Konradsson P, Udodong U, Fraser-Reid B. J Am Chem Soc 1988;110:5583-5584. 
a)
1) Ethylenediamine,
1) $\mathrm{PMe}_{3}, 0.1 \mathrm{M} \mathrm{NaOH}, \mathrm{THF}, 60^{\circ} \mathrm{C}$

$11 \underset{\text { n-butanol, } 130^{\circ} \mathrm{C}}{\stackrel{\text { 2) } \mathrm{Ac}_{2} \mathrm{O}, \mathrm{MeOH}, \mathrm{rt}}{\longrightarrow}}$

16

$\stackrel{\text { 2) } \mathrm{H}_{2}, \mathrm{Pd}(\mathrm{OH})_{2}, \mathrm{DCM}, \mathrm{AcOH},}{\mathrm{H}_{2} \mathrm{O}, \mathrm{MeOH}} \longrightarrow 1$

b) 1) Ethylenediamine, $53 \%$ for $14 \frac{\text { n-butanol, } 130{ }^{\circ} \mathrm{C}}{\text { 2) } \mathrm{Ac}_{2} \mathrm{O}, \mathrm{MeOH}, \mathrm{rt}}$

1) $\mathrm{PMe}_{3}, \mathrm{THF}, \mathrm{H}_{2} \mathrm{O}$, rt

four steps

$17 \frac{\text { 2) } \mathrm{H}_{2}, \mathrm{Pd}(\mathrm{OH})_{2}, \mathrm{DCM}, \mathrm{AcOH}}{\mathrm{H}_{2} \mathrm{O}, \mathrm{MeOH}}$

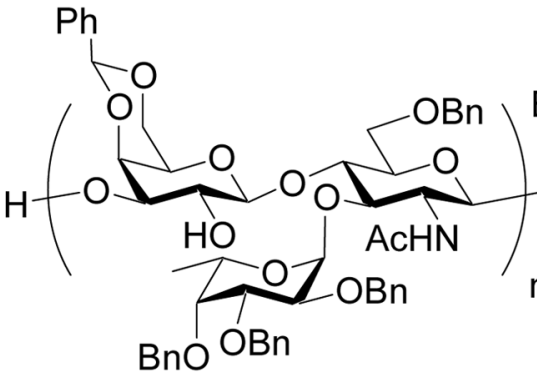<smiles>CC(C)OC(OCBr)C(Br)(Br)C(CBr)OCc1ccccc1</smiles>

16: $\mathrm{n}=1$

17: $n=2$

Scheme 1.

Deprotection of Lewis ${ }^{\mathrm{X}}$ and Dimeric Lewis $\mathrm{X}$ 

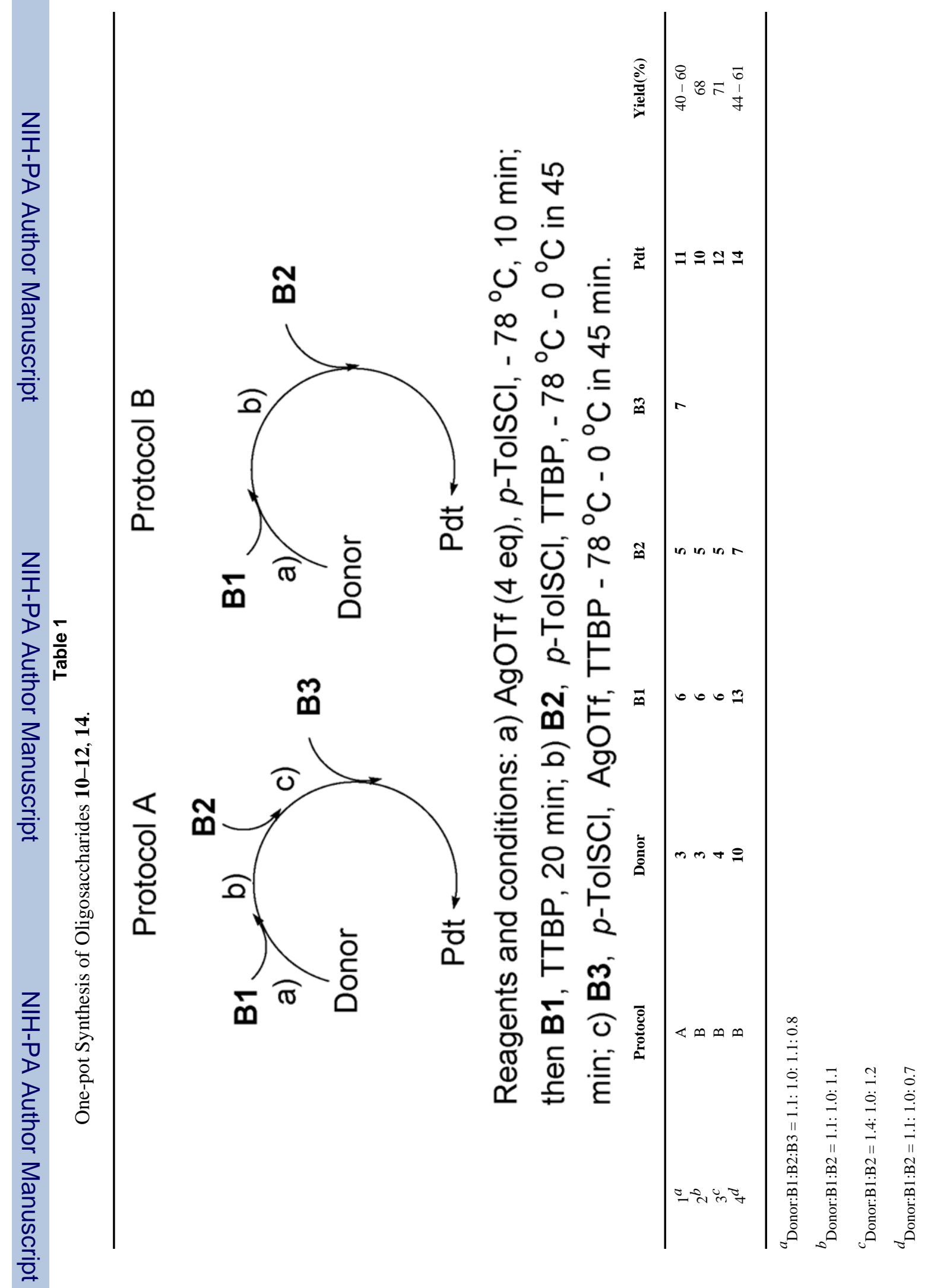